\title{
Endoscopic Drug and Gene Delivery Using Focused Ultrasonic Transducer
}

\begin{tabular}{|c|c|c|c|c|c|c|}
\hline 安居 & 晃啓 & (東北大院・工) & 正 & & 洋一 & (東北大・先進医工) \\
\hline 陳 & 俊傑 & (東北大院・工) & & 伊関 & 洋 & (東京女子医科大) \\
\hline 江刺 & 正善 & (東北大院・工) & 正 & 和田 & 仁 & 大院・工) \\
\hline
\end{tabular}

Akihiro YASUI, Tohoku University, Aza Aoba 1, Sendai 980-8579

Yoichi HAGA, Tohoku University Biomedical Engineering Research Organization (TUBERO) Jiun-Jie CHEN, Tohoku University

Hiroshi ISEKI, Tokyo Women's Medical University

Masayoshi ESASHI, Tohoku University

Hiroshi WADA, Tohoku University

Key Words: Sonodynamic therapy, Sonoporation, Ultrasonic transducer, Focused ultrasound, Drug delivery, Concave shape

\section{1. 緒言}

医療の分野において，超音波は体内軟組織の検査・診断に 広く用いられると共に, 近年は治療への応用にも期待が寄せ られている.特に, 音響感受性を持つ薬剤の細胞毒性を活性

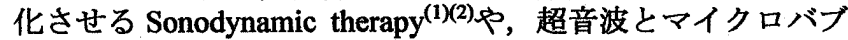
ルの併用で一時的に細胞・組織への薬刻や遺伝子の取り込み

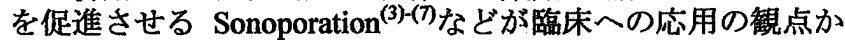
ら注目されている.

我々はこれら新しい超音波治療法を消化器などの体内哚 部の病巣に対して適応することを考えている.しかし，体外 からの超音波照射では，媒質の変化などによる反射，届折， 減衰の影響で体内深部における超音波の正確な位置合わせ や最適な強度の実現が困難となる.これに対して, 超音波卜 ランスデューサを内視鏡やカテーテルと組み合わせて体内 に持ち込み，超音波を照射し，治療を行うことが有効である と考えられる. そこで我々は，上記の目的に適した形状と大 きさ，機能を併せ持った超音波プローブの設計, 試作を行っ た.

本研究では, はじめに我々が提案する内視鏡, カテーテル を用いた超音波治療の概念について示す．次に，小型 PZT をポリマーの土台に組タ付けて作製した超音波プローブの 構造を示す. 続いて，試作した超音波プローブに対して，八 イドロホンを用いて行った音場分布の測定方法とその結果 について示す. 最後に, 試作した超音波プローブを用いて行 った Chinese Hamster Ovary (CHO) 細胞に対する Green Fluorescent Protein (GFP)プラスミドの遺伝子導入実験の方法 と結果について示す。

\section{2. デバイスの設計と作製}

2.1 体内からの超音波治療の概要 Fig. 1に体内からの超 音波治療の概要を示す. 先端に凹面型の集束超音波トランス デューサを持つ外径1-5 mm程度のプローブを, カテーテルま たは内視鏡に搭載, あるいは内視鏡の銣子口を通して体内に 挿入する(Fig. 1(a)). プローブが患部へ到達すると，プローブ 中央の貫通穴などを通して注射針を挿入し，薬昘を患部(例 えば癌組織)に注入する(Fig. 1(b)). その後, これらの穴を通 して超音波検查用ゲルを注入して空気を除き，超音波の減衰 を防ぐ(Fig. 1(c)). そして，その場で薬蝺を投与した患部に対 して集束超音波を照射することで局所的に楽剤の効果を引 き起こし，正常組織への影響は最小限に抑えることができる (Fig. 1(d)).

2.2 設計と作製 Fig. 1 の概念に従い設計, 試作を行った 超音波プローブの構造を Fig. 2(a)に示す. プローブは超音波 を発信する圧電セラミックス PZT, PZT を搭載するポリマー の土台, PZT を駆動する電極から構成されており, プローブ
の中心には将来的に薬剤や遺伝子, マイクロバブルなどを患 部へ注入するための直径 $0.5 \mathrm{~mm}$ の貫通穴を確保している. また, 局所的な治療と, 小型のデバイスでも必要とされる超 音波強度を実現するために, PZT は図に示すような外径 $5.5 \mathrm{~mm}$, 曲率半径 $9 \mathrm{~mm}$ の凹面形状とし, 超音波を収束させ る. 凹面型 PZT トランスデューサの作製に当たっては, 高 速立形加工機を用いて分極済みの PZT シートから切削加工 によって作製を行った. PZT の厚みは $1.1 \mathrm{~mm}$, この時の中 心周波数は 1.83 MHz で, Sonoporation で一般的に利用されて いる 1-2 MHz の範囲内に設定した. Fig. 2(b)に作製した超音 波プローブの写真を示す.

\section{3. 音場分布の測定}

3.1 測定方法 作製した収束超音波プローブに対して，八 イドロホンを用いて音場分布の測定を行った. Fig. 3 に測定 装置の構成を示す. 作製した超音波プローブを水槽内に固定 L, Function Generator (model 2416A; Pragmatic Instruments, Inc.) と高周波増幅器 (model 705810; YOKOGAWA)を用いて 凹面型 PZT に電圧を印加し超音波を発信させた. 音場分布 の測定に当たり,プローブの中心軸を Z 軸とし, 音源である 凹面型PZTトランスデューサから $9 \mathrm{~mm}$ 離れた $\mathrm{Z}$ 軸上の座標 を原点として X 軸, $\mathrm{Y}$ 軸を設定した. ハイドロホンはコンピ ユータ制御の 3 軸ステージで移動させ, 各点での強度の測定 を行い, 焦点付近における分布を調べた.

3.2 測定結果 始めに, $\mathrm{Y}=0 \mathrm{~mm}$ の XZ平面における強度 分布の測定を行った結果, $X=0 \mathrm{~mm}, Z=-3.3 \mathrm{~mm}$ の点で最

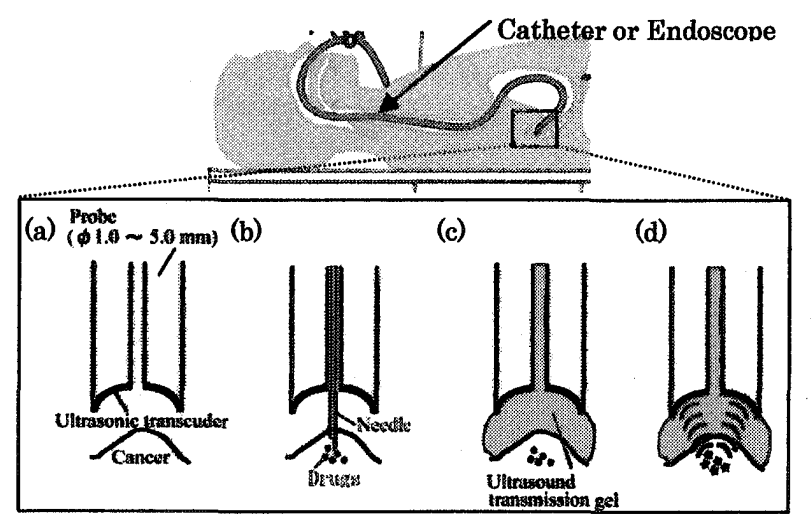

Fig. 1. Concept of localized ultrasonic treatment using focused ultrasonic transducer in the human body. (a) Insertion of the probe. (b) Injection of drugs. (c) Injection of the ultrasound transmission gel. (d) Enhancement of therapeutic effects and/or cytotoxicity of compounds. 
大音圧を記録し，焦点を確認した．次に，焦点面である $\mathrm{Z}=-3.3 \mathrm{~mm}$ の $\mathrm{XY}$ 平面に対して最大出力時に音場分布の測 定を行った. 測定の結果, 最大出力時の焦点における強度は 約 $25 \mathrm{~W} / \mathrm{cm}^{2}$ (0.87 MPa)であった(Fig. 4).

\section{4. 細胞人の遗伝子導入実臨}

4.1 実験方法 作製した超音波プローブの有効性を示すた めに, CHO 細胞に対して, 緑色蛍光蛋白を発現する GFP プ ラスミドの遺伝子導入実験を行った. Fig. 5 に実験の構成を 示す．作製した超音波プローブを水槽内に固定し，Function Generator と高周波増幅器を用いて凹面型 PZT に電圧を印加 し超音波を発信させた．水温は $37{ }^{\circ} \mathrm{C}$ に設定した．超音波の 照射はシャーレ越しに行い，超音波の焦点がシャーレの底面 に来るように調整を行った.

実験は培養液中の CHO 細胞に, $20 \mu \mathrm{g} / \mathrm{ml}$ の GFP プラスミ ドとシャーレ中の液量に対して $10 \%$ のマイクロバブル製剤 (MB-3, NEPA GENE)を加え，周波数 $1.83 \mathrm{MHz}$ ，最大音圧 $0.5 \mathrm{MPa}$ の連続波を 2 秒間照射した．照射後に培地交換を行 い, 24 時間培養後, Phosphate-Buffered Saline (PBS)下で蛍光 顕微鏡 (VF500, Olympus)を用いて, 細胞の観察を行った.

4.2 結果 超音波照射 24 時間後の蛍光顕微鏡による $\mathrm{CHO}$ 細胞の知察結果を Fig. 6に示す. 矢印で示した細胞で Fig. 6(b) のように緑色蛍光が観察され，細胞内における GFP の発現 を確認した。

\section{5. 考察}

今回試作した超音波プローブは外径が $5.5 \mathrm{~mm}$ である.こ の大きさでは内視鏡の鉜子口を通す，あるいはカテーテルに 搭載するには大きすぎるので今後はデバイスの細径化を試 みる．この際には，プローブへ音響整合層を追加し，超音波 の伝播を効率良く行う必要がある。

また，本報告では遺伝子導入の確認のみを行った. 今後は 遺伝子導入效率の確認と, ex vivo で組織を用いた遺伝子導入 実験を試みる。

\section{6. 結言}

体内から超音波治療を行うための凹面型 PZT を用いた外 径 $5.5 \mathrm{~mm}$ の収束超音波プローブを作製した。 そして，試作 した収束超音波プローブを用いて，CHO 細胞に対して GFP プラスミドの遺伝子導入実験を行った結果，超音波照射 24 時間後に細胞内で GFP の存在を確認した. 従って，内視鏡 治療に用いることができる程度の大きさの PZT トランスデ ユーサで実際に遺伝子導入が可能であると言える.

\section{参考文献}

(1) Rosenthal, I Sostaric, JZ and Riesz, P, Sonodynamic therapy-a review of the synergistic effects of drugs and ultrasound, Ultrason. Sonochem., 11, 349-363, 2004.

(2) Misik, V., Riesz, P., Free radical intermediates in sonodynamic therapy, Ann. NY Acad. Sci., 899, 335-348, 2000.

(3) Greenleaf, W.J., Bolander, M.E., Sarkar, G., Goldring, M.B. Greenleaf, J. F., Artificial Cavitation Nuclei Significantly Enhance Acoustically Induced Cell Transfection, Ultrasound in Med. \& Biol., 24, 587-595, 1998.

(4) Taniyama, Y., Tachibana, K., et al, Local Delivery of Plasmid DNA Into Rat Carotid Artery Using Ultrasound, Circulation, 105, 1233-1239, 2002.

(5) Lawrie, A., Brisken, A.F., Francis, S.E., Cumberland, D.C. Crossman, D.C., Newman, C.M., Microbubble-enhanced ultrasound for vascular gene delivery, Gene Therapy, 7, 2023-2027, 2000.

(6) Kinoshita M., Hynynen, K. Intercellular Delivery of Bak BH3 Peptide by Microbubble-Enhanced Ultrasound, Pharm. Res., 22, 716-720, 2005.

(7) Kinoshita, M., Hynynen K., A novel method for the intercellular delivery of siRNA using microbubble-enhanced focused ultrasound, Biochem. Biophys. Res. Commun., 335, 393-399, 2005.
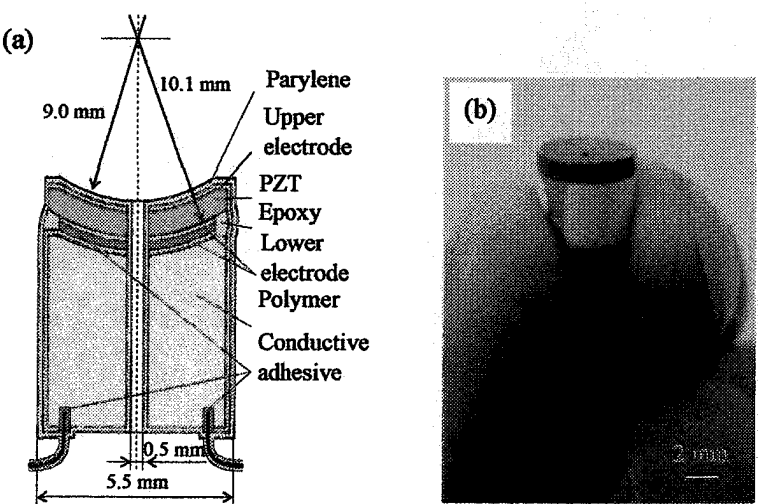

Fig. 2. Fabricated focused ultrasonic probe. (a) Cross-sectional view. (b) Oblique photograph.

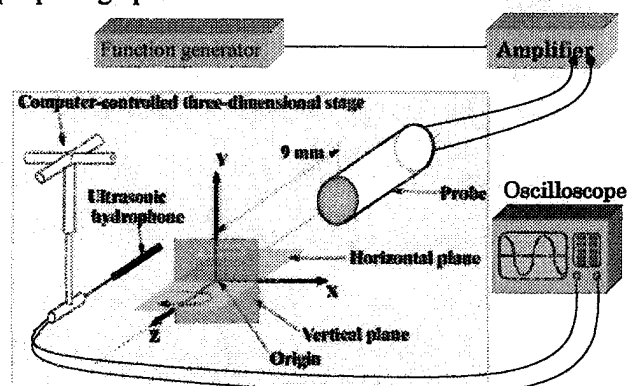

Fig. 3. Acoustic field measurement system used in this study. The fabricated ultrasonic probe was fixed in water bath and driven using the function generator and amplifier. Ultrasound generated by the probe was detected by the ultrasonic hydrophone moved in steps of $0.3 \mathrm{~mm}$ using the computer-controlled three-dimensional stage.

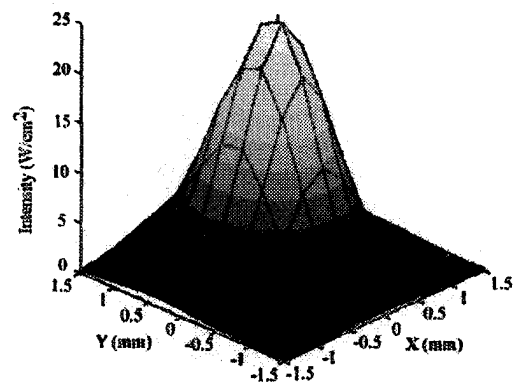

Fig. 4. Ultrasonic intensity distribution on focal plane $(X-Y$ plane $(Z=$ $-3.3 \mathrm{~mm}$ )) by a $120 \mathrm{Vp}-\mathrm{p} \mathrm{AC}$ signal at $1.83 \mathrm{MHz}$. The intensity at focal point was about $25 \mathrm{~W} / \mathrm{cm}^{2}(0.87 \mathrm{MPa})$

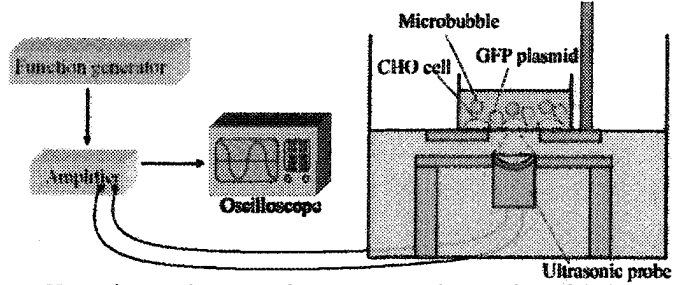

Fig. 5. Experimental setup for sonoporation using fabricated focused ultrasonic probe. The culture dish was placed above the probe. $\mathrm{CHO}$ cells were exposed to $1.83 \mathrm{MHz}$ continuous ultrasound through the bottom of the dish for $2 \mathrm{~s}$ in the presence of $10 \%$ microbubbles (MB-3) and 20 $\mu \mathrm{g} / \mathrm{ml}$ GFP plasmid DNA.
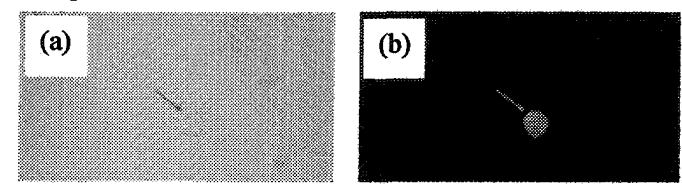

Fig. 6. CHO cell expressing GFP (arrow). (a) Transmission image. (b) Fluorescence image. Successfully sonoporated cell emits green fluorescence resulting from GFP expression. 